Case Study

\title{
Community-based Forest Resources Management in Nigeria: Case study of Ngel Nyaki Forest Reserve, Mambilla Plateau, Taraba State, Nigeria
}

\author{
T.I. Borokini*1, F.D, Babalola ${ }^{2}$, T.O. Amusa ${ }^{3}$, S.T. Ivande ${ }^{4}$, Z.J. Wala ${ }^{4}$, O.O. Jegede ${ }^{5}$, \\ D. Tanko ${ }^{6}$, and J.O. Ihuma ${ }^{7}$ \\ ${ }^{1}$ National Centre for Genetic Resources and Biotechnology, P.M.B 5382, Ibadan, Nigeria \\ ${ }^{2}$ Department of Forest Management and Policy, University of Ilorin, Ilorin, Nigeria \\ ${ }^{3}$ Forestry Research Institute of Nigeria (FRIN), New Bussa, Nigeria \\ ${ }^{4}$ AP Leventis Ornithological Research Insitute (APLORI), Jos, Nigeria \\ ${ }^{5}$ Nigeria Conservation Foundation (NCF), Lagos, Nigeria \\ ${ }^{6}$ Ahmadu Bello University (ABU), Zaria, Nigeria \\ ${ }^{7}$ Department of Biological Sciences, Bingham University, Nigeria
}

Date Received: 18-12-2011～Date Accepted: 28-03-2012

\begin{abstract}
In Nigeria, human communities are found within or beside forest ecosystems, depending on these ecosystems for survival. Their forest exploitation is considered a threat to conservation efforts, leading to constant conflicts between Government, law enforcement agencies and the communities. The best solution is a win-win system of participatory community-based forest resources management, in which the communities are regarded as stakeholders rather than as threats. This paper explains the adoption of this approach in Ngel Nyaki Forest Reserve, Mambilla Plateau, where the communities were trained in establishment and management of forest plantations with readily available market for their timber; employment for some of the community youths as well as community development projects. This paper calls for the adoption of this system in other protected areas in Nigeria, while the Government should provide basic amenities for the communities as alternatives to those forest products.
\end{abstract}

Keywords: Community-based forest management, Ngel Nyaki Forest Reserve, Protected areas, Nigeria.

\section{Introduction}

From time immemorial, human settlements have been associated with tropical forests, and to date, in Nigeria, human settlements are found within or beside forest regions, mostly the rural dwellers, whose lives and existence are solely dependent on the forests and their resources. For instance, in Omo Biosphere Reserve, Southwest Nigeria, there are about 20 enclaves inside the reserve, mainly located on the periphery, and four timber camps and one small town. There are an estimated 20,000 inhabitants living inside the reserve (Amador and Uijetwaal, 1997) and during the dry season there is a temporary influx of Hausa people from the north, Igbo people from the east and non-Nigerians (Perrson and Warner, 2003). Greengrass (2006) noted that most of the inhabitants are farmers and timber workers, indicating that their livelihood depend on the forests.

*Corresponding author: tbisrael@gmail.com,

Tel: +2348054506902

ISSN 2235-9370 Print / ISSN 2235-9362 Online (C2012 University of Sri Jayewardenepura 
Nigerian moist forests are rich in epiphytic ferns and orchids, and contain over 560 species of trees which attain heights of at least 12 metres and girth of 60 centimetres. Due to the relatively large number of plant species identified, Nigeria has been ranked the 11th in biodiversity in Africa. In addition, the West African Forests is one of the 25 biodiversity hotspots of global significance for conservation priorities (Myers et al., 2000) and the Nigerian tropical rainforests form a significant part of this (Borokini et al., 2010).

However, due to massive logging, fuelwood harvesting, poaching and expansion of agricultural lands, Nigeria is losing many of her natural forests and their wildlife. Nigeria was adjudged to have the highest rate of deforestation of primary forests having lost $55.7 \%$ of her natural forests between 2000 and 2005 (FAO, 2006). The FAO 2005 Forest Resources Assessment further revealed that, poor tropical countries have the highest rate of deforestation (FAO, 2006). As a result, as many as $58(10.4 \%)$ of the tree species are listed as endangered (FORMECU, 1999). This biodiversity loss occurs in spite of the establishment of forest reserves, protected areas and associated conservation and environment laws. This indicates partial or total failure of these legal and institutional frameworks for nature conservation in Nigeria. A good example of this was reported by Greengrass (2006) in her studies on chimpanzees in Southwest Nigeria, that in most of the forest reserves visited, the state and local forest departments are unable to control the large-scale illegal activities taking place within the forest reserves.

While the timber industries are being blamed for the illegal and excessive logging, the rural dwellers are accused of deforestation for fuelwood and farmland expansion. However, it is difficult, if not totally impossible to stop rural dwellers that live close to the forest from entering the forests because of conservation laws. These people have been depending on the forests from several centuries back and worse still, their illiteracy and poverty level is very high. Over $70 \%$ of the population in Sub-Saharan Africa (SSA) lives in rural areas where most households depend on forests and woodlands for their livelihoods (Topa, 2005). While agricultural activities meet most of their subsistence needs, forest products - timber and non-timber forest products (NTFPs) - provide a substantial part of the disposable income for at least 20 percent of rural families.

In many protected areas in Nigeria, there are active or passive conflicts on natural resource control between the Government/Government staff and the rural dwellers. The only viable solution is to consider these local people as stakeholders for effective conservation of these natural ecosystems earmarked as protected areas. This concept is called Community-based Forest Resources Management (CBFRM), which is synonymous to Community-based Natural Resources Management (CBNRM), or simply called community forestry.

Community forestry was defined by FAO as "any situation which intimately involves local people in a forestry activity. It embraces a spectrum of situations ranging from woodlots in areas which are short of wood and other forest products for local needs, through the growing of trees at the farm level to provide cash crops and the processing of forest products at the household, artisan or small industry level to generate income, to the activities of forest dwelling communities" (FAO, 1978). It primarily entails involving the local communities in conservation of the forests around them, training them on tree plantation and management, integrating tree planting with food crop cultivation (agroforestry), employment of some of the local people as staff of the protected area, community development projects as well as involving the people in the formulation of conservation policies. Currently, the practice of CBNRM is very limited in Nigeria (Babalola, 2009).

Taungya system was probably the oldest method of community participation in forest management, introduced by Richard St. Barber Baker in 1926 (Bada, 1999). Since then, several other practices such as agroforestry have been introduced, but it appears that most of these practices are not being used in most of the protected areas in Nigeria. Furthermore, as much as agroforestry is effective in forest management, it does not consider or favour other important biological components of the forest 
ecosystem, such as the wildlife, shrubs, herbs and epiphytes, which have their equally important economic and ecological significance. Therefore, this paper describes community participation in the management of Ngel Nyaki Forest reserve, as a way to advocate for best practices in community forest management in Nigeria.

\section{Ngel Nyaki Forest Reserve}

Ngel Nyaki is located towards the western escarpment of the Mambilla Plateau. Mambilla Plateau is the highest plateau in Nigeria with the mean altitude of 1,524metres (5,000 feet) above the sea level, while some hills are much higher, such as Chappal Waddi (the highest mountain in Nigeria) which is 2,419 metres (7,936 feet) high. Mambilla Plateau is located in Taraba state, North-eastern part of Nigeria, and it is characterised by semi-temperate climate.

There are about 15 forest fringes on the Mambilla Plateau, which include Ngel Nyaki Forest Reserve, Leinde Fadali, Sarkaka, Ndum Yaji, and other fringing forests; but Ngel Nyaki Forest Reserve is the most diverse forest (Chapman \& Chapman 2001). Figure 1 shows the location of all the protected areas, including Ngel Nyaki Forest Reserve on Mambilla Plateau. Ngel Nyaki Forest is made up of a main forest and three forest fragments separated by hills covered by montane grasslands. The reserve is situated between latitudes $07^{\circ} 05^{\prime} \mathrm{N}$ and longitude $011^{\circ} 05^{\prime} \mathrm{E}$ at an altitude of $1,400 \mathrm{~m}-1,600 \mathrm{~m}$ above sea level. The Reserve occupies about $46 \mathrm{~km}^{2}$ area of land, with about $7.2 \mathrm{~km}^{2}$ of sub-montane to midaltitude forest. It was gazetted a Local Authority Forest Reserve under Gashaka Mambilla Native Authority Forest Reserve Order of 24 April 1969. Plate 1 shows the topography and part of the forests in Ngel Nyaki Forest Reserve.

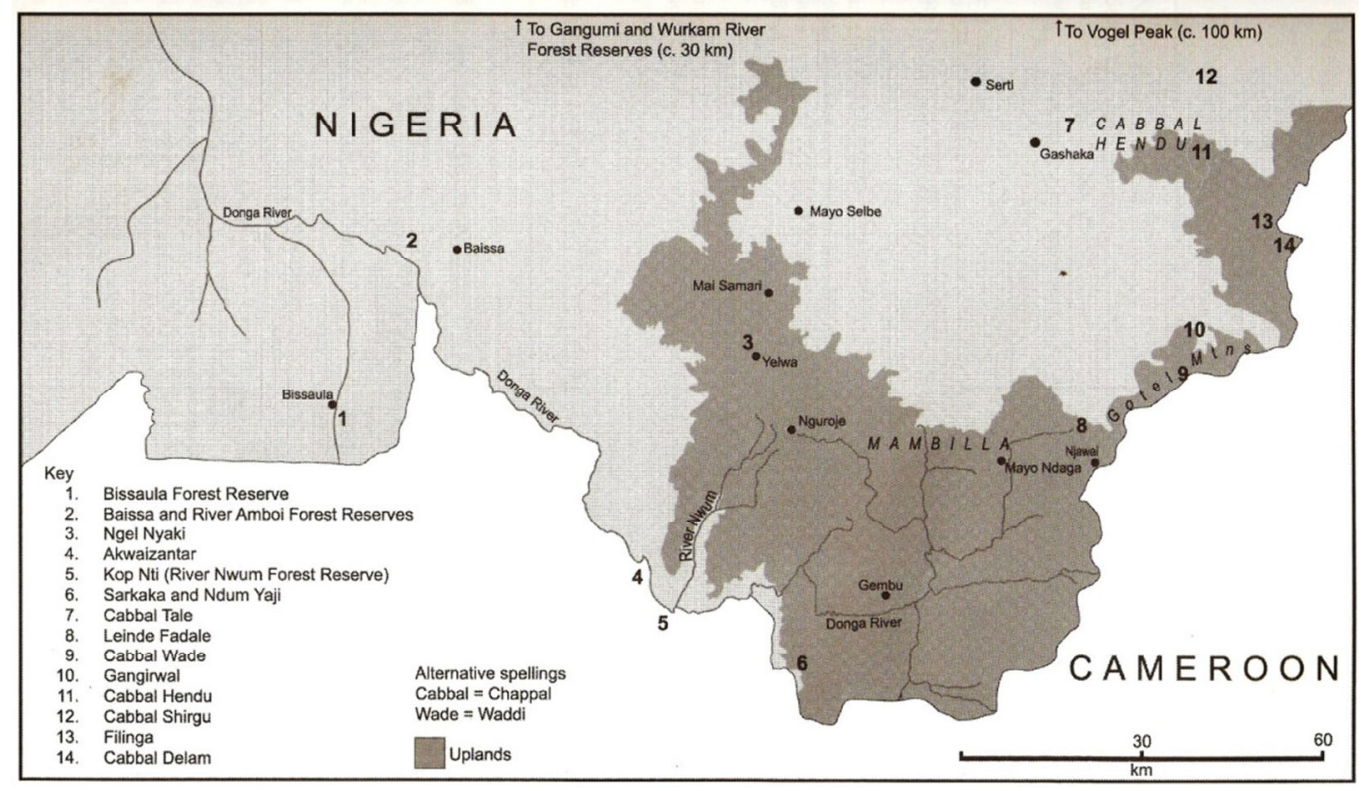

Figure 1: Map showing Mambilla Plateau, Taraba State, Nigeria

(Source: Chapman and Chapman, 2001)

Ngel Nyaki forest harboured several threatened species and others unknown at that time elsewhere in West Africa (Anthonotha noldeae, Apodytes dimidiata and Pterygota mildbraedii) and Nigeria (Ficus chlamydocarpa and Isolona cf. deightonii) (Dowsett-Lemaire, 1989). This diverse forest flora was reflected in the high number of primates and other animal species, and high bird species diversity (Hall 1976, Ash et al., 1989). Over 146 vascular plant species have been identified and collected by Dr. J.D Chapman, many of which are trees and are endemic to the Afromontane region. 
Furthermore, some of them are listed in the IUCN Red Data - Entandrophragma angolense, Lovoa trichiloiodes, Millettia conraui and Pouteria altissima - some others are new additions to the West Africa Flora - Pterygota mildbraedii, Anthonotha noldeae and Apodytes dimidiata. Furthermore, plants such as Isolona cf deightonii and Ficus chlamydocarpa are new to Nigerian flora. Till date, there are still many plants in the forest that are yet to be identified, and they are suspected to be new plants (Chapman and Chapman, 2001).
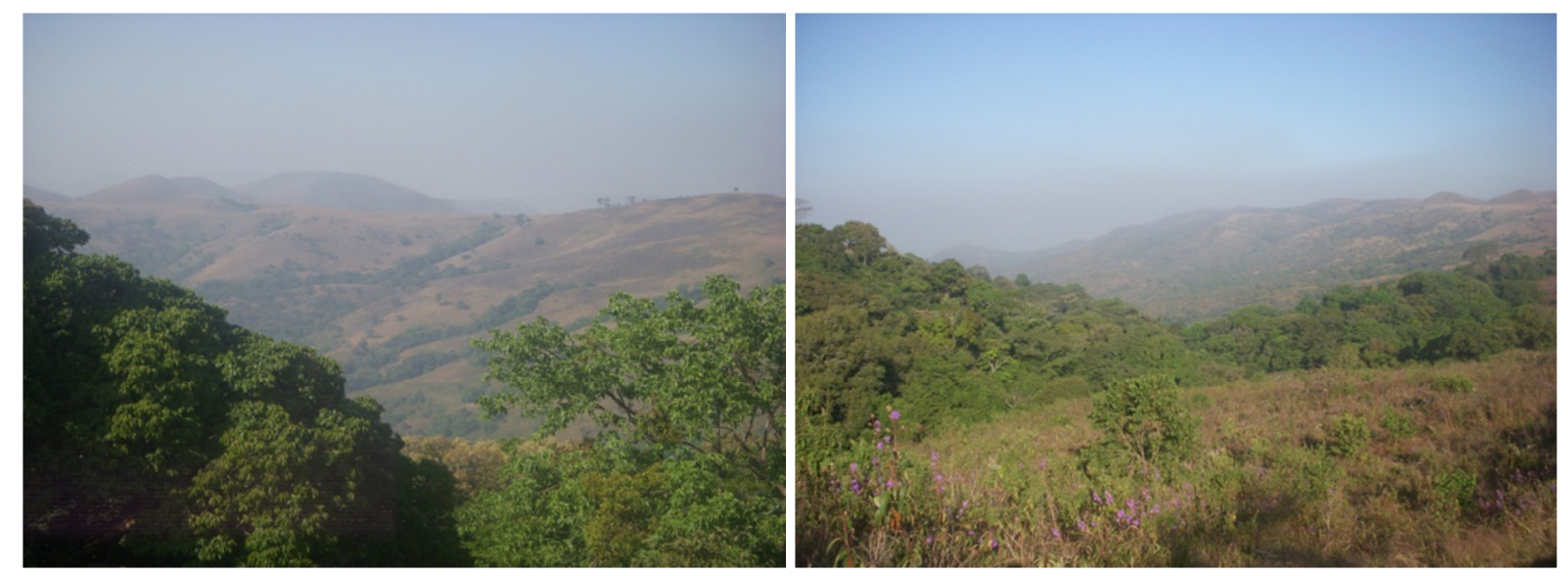

Plate 1: Photograph showing a section of Ngel Nyaki Forest Reserve

Associated with the wide floristic diversity are corresponding faunal diversity of large several herds of tantalus monkeys, duikers, birds, colobus monkeys, mountain gorillas, the Red Data Listed Chimpanzee, Pan troglodytes subsp. vellerosus, putty nose monkeys (Cercopithecus nictitans cf subspecies martini) and black and white colobus monkeys (Colobus guereza occidentalis). Oates (2000, pers. comm.) noted that the Chimpanzees in the montane and submontane forests belong to the distinct subspecies Pan troglodytes vellerosus listed as 'endangered' by the IUCN Primate Specialist Group (IUCN, 2000). He also noted that the putty-nose monkey (Cercopithecus nictitans, cf subspecies martini) needs taxonomic review and suspects that the Mambilla putty noses may be different from those in the Gashaka lowlands. Furthermore, 10 buffalo Syncerus caffer were also sighted. Ngel Nyaki is also classified as an Important Bird Area (Fishpool and Evans, 2001). Snakes and other terrestrial reptiles are very rare there due to the very cold weather on the plateau which is unfavourable to the poikilothermic nature of the snakes. The Table 1 gives a list of the economic plants found in the area that are listed in the IUCN Red Data List (IUCN 2000). Plate 2 depicts the some of the biodiversity of the Ngel Nyaki Forest Reserve.

\section{Community-participation in Forest management in Ngel Nyaki Forest}

\subsection{The People}

The area is populated by Mambilla people and Fulani herders. The Mambilla People are primarily farmers. Yelwa village appears to be the closest to the Ngel Nyaki Forest Reserve, a distance of about 40 minutes trekking. They cultivate maize for corn flour meal (tuwo). Mairiga (pers. comm.) stated that 'Nyaki' means 'bean', suggesting that they might have been cultivating beans in the past. The major agricultural crops here are coffee and tea, which are cultivated and sold in large quantities. Mambilla Plateau is the home to Nigeria and West Africa's only highland tea plantations. Towns on the Mambilla Plateau are small with populations ranging from 100 to 5,000 people, which include Gembu (the largest town), Dorofi, Nguroje, Ngelforo, Wakili Buba and Maisamari. Other agricultural crops include plantain, a special variety of pepper which when ripe, the flesh is yellowish-orange instead of the common red colored ripe pepper fruits; and a special variety of yam that resembles cocoyam. The 
Fulani people are cattle herders settling on the hills where they get grass for their animals. They also sell raw milk, cheese and yoghurt.

Table 1: List of Plants in Ngel Nyaki Forest Reserve that are present in the IUCN 2000 Red Data List

\begin{tabular}{|c|c|c|}
\hline $\mathrm{S} / \mathrm{N}$ & Plant name & Family \\
\hline 1 & Peucedanum angustisectum (Engl.) Norman & Apiaceae \\
\hline 2 & Lobelia columnaris Hook. f. & Campanulaceae \\
\hline 3 & $\begin{array}{l}\text { Wahlenbergia ramosissima (Hemsley) Thulin sub-sp } \\
\text { ramosissima }\end{array}$ & Campanulaceae \\
\hline 4 & Bafutia tenuicaulis C.D Adams & Asteraceae \\
\hline 5 & Helichrysum cameroonense Hutch \& Dalziel & Asteraceae \\
\hline 6 & Vernonia bamendae C.D Adams & Asteraceae \\
\hline 7 & Stachys pseudohymifusa sebsebe subsp saxeri Y.B Harv. & Lamiaceae \\
\hline 8 & Crotalaria bamendae Hepper & Leguminosae \\
\hline 9 & Crotalaria ledermanii Baker f. & Leguminosae \\
\hline 10 & Millettia conraui Harms & Leguminosae \\
\hline 11 & Entandrophragma angolense (Welw.) C.DC & Meliaceae \\
\hline 12 & Khaya grandifoliola C.DC & Meliaceae \\
\hline 13 & Lovoa trichilioides Harms & Meliaceae \\
\hline 14 & Eugenia gilgii Engl. \& Brehm & Myrtaceae \\
\hline 15 & Polygala tenuicaulis Hook f. subsp. Tayloriana J. Paiva & Polygalaceae \\
\hline 16 & Prunus africana Hook f. & Rosaceae \\
\hline 17 & Chassalia laikomensis Cheek ined. & Rubiaceae \\
\hline 18 & Pouteria altissima (A. Chev.) Baehni & Sapotaceae \\
\hline 19 & Dombeya cf. ledermanii & Sterculiaceae \\
\hline 20 & Carex preusii K. Schum & Cyperaceae \\
\hline 21 & Eriocaulon asteroids S.M Phillips & Eriocaulaceae \\
\hline 22 & Eriocaulon bamendae S.M Phillips & Eriocaulaceae \\
\hline 23 & Raphia mambillensis Otedoh & Araceae \\
\hline 24 & Xyeris sp. & Xyridaceae \\
\hline 25 & Irvingia gabonensis & Irvingiaceae \\
\hline
\end{tabular}

\subsection{Community participation in forest management}

When Ngel Nyaki forest was to be designated a forest reserve, Yelwa community was relocated to its present location, perhaps one of the very few successful relocation of communities from the forest in Nigeria. Later, Nigerian Montane Forest Project (NMFP) was established by the University of Christchurch, New Zealand for research in biodiversity conservation and forest ecology. Ngel Nyaki Forest Reserve appears to be safe from deforestation and bush meat hunting. Several of the Yelwa community and staff of NMFP were interviewed informally in addition to personal observations, yielding the following explanations:

1. Forest plantations: Several local communities, including Yelwa, were trained in planting, seedling and field management of fast woods, especially Eucalyptus spp. (Figure 2) which they grow in large quantity and within 6-10 years, they harvest and transport them to nearby towns, such as Gembu, Mutum Biyu, Jalingo, Katsina Ala, Makurdi and other areas in the Northeastern Nigeria. The timber from Eucalyptus is used for building and construction purposes, as well as the young boles are used as poles and mainly as firewood. This was observed as a great source of income to the people because Eucalyptus is a fast growing wood. Harvesting was done in such a way that the felled tree can regenerate naturally. In this way, no one goes into the forests to fell the trees. 

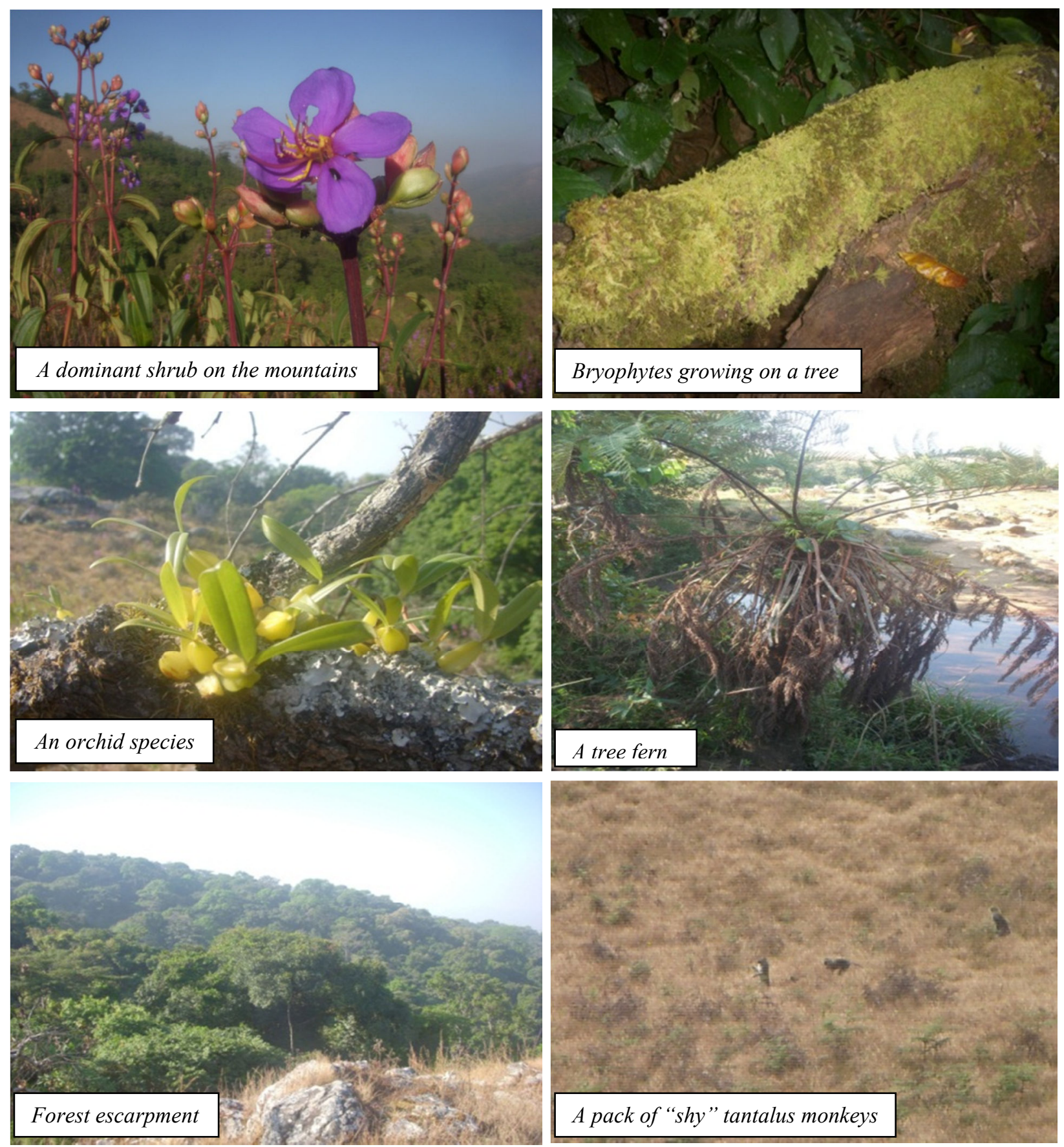

Plate 2: Photographs illustrating the biodiversity of Ngel Nyaki Forest Reserve

2. Employment: Virtually all the staff of the Forest Reserve and NMFP are local people of Yelwa community. This makes security of the forest reserve very effective and it also enhances community cooperation with the forest reserve staff.

3. Community Development Project: Funded by the EssoMobil Oil Company, the NMFP built a nursery school for the Yelwa community. This was not available in the community before then, and it was made free for them to allow their children have access to education.

Several other areas of community forestry that need to be given serious consideration in Nigeria include working out a sharing formula between the Government and the local communities for the proceeds from the sales of forest resources or tourism; for which the local communities must have a 
larger share. Furthermore, local people should be encouraged to make and sell local wares, like arts and crafts to tourists that visit protected areas around them, community development projects such as production of methane (biogas) from waste products and dumps for energy generation to replace fuelwood harvesting and burning.

In addition, Biodiversity offset projects, in which industries help financing biodiversity conservation projects as a way of paying for industrial wastes they release into the environment is very limited in Nigeria. Only very few industries are funding biodiversity projects.

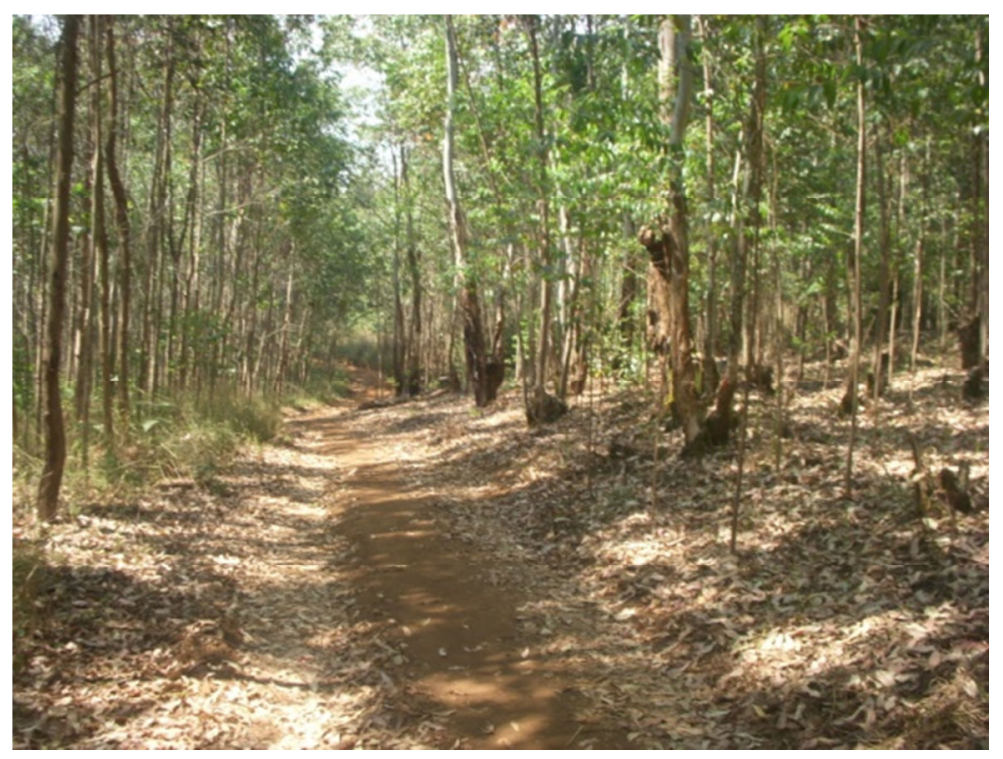

Figure 2: Eucalyptus plantation managed by the Yelwa community

\section{Conclusion}

Unless the local communities neighbouring protected areas are considered an important stakeholder in the management of the protected areas, there can never be a successful conservation of the nation's biodiversity. The most effective way to do this is to give these local people a cheaper and more accessible alternative to the resources they get from the forests - mainly fuelwood and bush-meat in addition to community development projects, employments in the protected areas to their people, sharing of proceeds from the forests with the communities for sustainable development projects, favourable land policies to encourage land ownership for individual afforestation micro-businesses and source of livelihood, which may be through small-scale businesses, afforestation projects, bushmeat rearing among others. It should be noted that full cooperation of these communities are pivotal to successful biodiversity conservation.

\section{Acknowledgment}

The study was funded through the 2010 Small Grant Progamme of Tropical Biology Association (TBA). We are also grateful to Dr. Hazel Chapman, Director of Nigerian Montane Forest Project, for granting us the permission to conduct the research in Ngel Nyaki Forest Reserve.

\section{References}

Amador, M.R., Uijetwaal, A.A.C., 1997. Towards a sustainable management of the Omo Forest Reserve, Ogun State, Nigeria. Unpublished report, Nigerian Forest Elephant Group. 
Ash, J.S., Dowsett, R.J., Dowsett-Lemaire, F. 1989. New ornithological distribution records from eastern Nigeria. In Dowsett, R.J. Tauraco Research Report 1. Tauraco Press, Ely, UK.

Babalola, F.D. 2009. Joint Forest Management (JFM): opportunity for implementation of rural development in Cross River State, Nigeria. African Scientist 10 (3): 127-137.

Bada, S.O, 1999. Community Participation in the Management of Omo Forest Reserve. Prepared for FORMECU, Federal Department of Forestry, Abuja, Nigeria, 23-30.

Borokini, T.I., Okere, A.U., Giwa, A.O., Daramola, B.O., Odofin, W.T., 2010. Biodiversity and conservation of plant genetic resources in Field Genebank of the National Centre for Genetic Resources and Biotechnology, Ibadan, Nigeria. International Journal of Biodiversity and Conservation 2(3): 037-050.

Chapman, J.D., Chapman, H.M., 2001. The Forests of Taraba and Adamawa States, Nigeria. An Ecological Account and Plant Species Checklist. University of Canterbury, Christchurch, New Zealand, 5-27.

Dowsett-Lemaire, F., 1989. Physiography and vegetation of the highland forests of eastern Nigeria. Tauraco Research Report, 1, 6-12.

Greengrass E.J., 2006. A survey of Chimpanzees in South-west Nigeria. NCF-WCS Biodiversity Research Programme. Unpublished report.

FAO., 1978. Forestry for local community development. Forestry Paper 7, FAO, Rome.

FAO. 2006. Global Forest Resources Assessment 2005. FAO Forestry Paper 147, Rome.

Fishpool, L.D.C., Evans, M.I., 2001. Important Bird Areas in Africa and Associated Islands. Pisces Publications, Newbury, UK, 42-46.

FORMECU, 1999. Forest Resources Study, Nigeria. Revised National Report Vol. 2. Prepared for FORMECU by Beak and Geomatics International, 87-99.

Hall, P. 1976. The birds of Mambilla Plateau. Bulletin of the Nigerian Ornithological Society, 12, 6772.

IUCN 2000. IUCN Red Data List Categories. IUCN, Gland, Switzerland.

Myers N., Mittermeier RA., Mittermeier CG., de Fonseca GAB., Kent J., 2000. Biodiversity hotspots for conservation priorities. Nature 403.

Perrson, H.M., Warner, M.D., 2003. The Chimpanzees and other primates of Omo Forest Reserve. The Nigerian Field 68: 160-167.

Topa G., 2005. Framework for Forest Resource Management in Sub-Saharan Africa. Africa Region Working Paper Series number 89. The World Bank. 137pp. 